\title{
ESTABLISHMENT OF XARAÉS AND MARANDU GRASSES UNDER LEVELS OF SOIL COMPACTION
}

\section{EDNA M. BONFIM-SILVA ${ }^{1}$, DANIEL D. VALADÃO JÚNIOR ${ }^{2}$, RAFAEL H. P. DOS REIS ${ }^{2}$, JADER J. CAMPOS ${ }^{3}$, WALCYLENE L. M. P. SCARAMUZZA ${ }^{4}$}

\begin{abstract}
In Cerrado soils under grazing, changes occur in physical attributes, such as increased density, decreasing on the size of water stable aggregates, and macroporosity reduction. Thus, the aim of this study was to study the effect of compaction on the establishment of two forages. It was adopted a completely randomized design with three replications, in $2 \times 4$ factorial design, and two forages (Xaraés grass and Marandu grass), and four levels of compaction (soil densities of $1.0,1.2,1.4$, and $1.6 \mathrm{Mg} \mathrm{m}^{-3}$ ). The following variables were evaluated 48 days after sowing: tiller population, plant height, dry matter production of shoots and components, leaf and stem, as well as the root dry mass. The stem dry mass decreased with soil density in a similar manner for both forages. It was observed that the leaf dry mass and shoots dry mass of Xaraés grass remained constant in the levels of soil compaction, not adjusting to any regression model. The establishment of Xaraés grass has not been negatively affected by compaction, which may be suitable for situations where there may be layers that restrict the growth of different forages.
\end{abstract}

KEYWORDS: Brachiaria brizantha, soil density, forage, tillering.

\section{ESTABELECIMENTO DOS CAPINS-XARAÉS E MARANDU SOB NÍVEIS DE COMPACTAÇÃO DO SOLO}

RESUMO: Em solos de Cerrado manejados sob pastejo, ocorrem alterações em suas propriedades físicas, como aumento na densidade, diminuição do tamanho dos agregados estáveis em água e redução da macroporosidade. Então, teve-se o objetivo de estudar o efeito da compactação sobre o estabelecimento de duas gramíneas forrageiras. Foi adotado o delineamento inteiramente casualizado, com três repetições, arranjado em esquema fatorial 2 x 4, sendo duas gramíneas forrageiras (capim-xaraés e capim-Marandu) e quatro níveis de compactação (densidades de solo 1,$0 ; 1,2 ; 1,4 \mathrm{e} 1,6 \mathrm{Mg} \mathrm{m}^{-3}$ ). Foram avaliadas aos 48 dias após a semeadura as seguintes variáveis: número de perfilhos, altura das plantas, produção de massa seca da parte aérea e dos componentes, lâmina foliar e colmo, bem como a produção de massa seca das raízes. A massa seca de colmo reduziu-se com a densidade do solo de maneira similar para as duas forrageiras. Foi observado que a massa seca foliar e a massa seca da parte aérea do capim-xaraés permaneceu praticamente constante nos níveis de compactação do solo, não se ajustando a qualquer modelo de regressão. $\mathrm{O}$ estabelecimento do capim-xaraés não foi afetado negativamente pela compactação, podendo ser indicado para situações em que possam ocorrer camadas que restrinjam o crescimento de outras espécies forrageiras.

PALAVRAS-CHAVE: Brachiaria brizantha, densidade do solo, forrageira, perfilhamento.

\footnotetext{
${ }^{1}$ Professor Adjunto, Universidade Federal de Mato Grosso, Câmpus Universitário de Rondonópolis, Instituto de Ciências Agrárias e Tecnológica, Rondonópolis - MT, embonfim@ hotmail.com.

${ }^{2}$ Doutorando, Programa de Pós-Graduação em Agricultura Tropical, Universidade Federal de Mato Grosso, Cuiabá - MT.

${ }^{3}$ Mestrando, Programa de Pós-Graduação em Agricultura Tropical, Universidade Federal de Mato Grosso, Cuiabá - MT.

${ }^{4}$ Professor Adjunto, Universidade Federal de Mato Grosso, Cuiabá - MT.

Recebido pelo Conselho Editorial em: 15-3-2011

Aprovado pelo Conselho Editorial em: 23-4-2012
}

Eng. Agríc., Jaboticabal, v.32, n.4, p.727-735, jul./ago. 2012 


\section{INTRODUCTION}

Compaction commonly occurs in soils of grazing areas, which occupy a large amount of land in the Brazilian state of Mato Grosso. In these areas, the main cause of changes in soil physical properties is related to animal trampling. AZEVEDO \& SVERZUT (2007) found that in grazing from Mato Grosso, the trampling of cattle favors the compaction of the soil surface layer, as evidenced by an increase in soil density and soil resistance to penetration, and reduction of the macroporosity, the total porosity and hydraulic conductivity.

The literature has revealed that in grazing may occurs an increase in the resistance from soil to penetration of up to 2.6 times greater than the tolerated for the development of roots, which intensifies the degradation process (SILVA FILHO et al., 2010; FERREIRA et al., 2010). SILVA et al. (2008) have found physical changes in soil to a depth of $0.15 \mathrm{~m}$, but with greater severity in the layer from 0.05 to $0.10 \mathrm{~m}$, both in conventional grazing, and in area of natural Cerrado, under grazing. SARMENTO et al. (2008) have measured that the largest cattle trampling due to the increase in forage production, increases the percentage of micropores and reduces the marcroporos, in 0 to $0.05 \mathrm{~m}$. Moreover, SPERA et al. (2006) have found that soils under crop-livestock integration, present evidences of disintegration, however, they have not reached levels considered critical for the production of both components of the system.

The plant response to soil compaction presents variation between crops and cultivars. The millet ADR 500 shows a good capacity of breaking compacted layers, maintaining good production of shoots, as well as adequate root length density (GONÇALVES et al., 2006). In Argisol, the Tifton 85 grass has been shown to be a forage able to promote decompaction of the soil (SEVERIANO et al., 2010). However, it has been found that plant roots grown in soil with compaction show morphological changes. Thus, a decrease in cell division in the meristem and increase in root diameter, due to the increase in the thickness of cortex, reduces the area of explored soil by the roots, and thus, the absorption of water and nutrients (BENGOUGH et al., 1997). According to the former authors, in adverse conditions of growth, the roots send signals to the shoot indicating that the conditions for development of the plant are being restricted and it is necessary to reduce the growth rate, resulting in lower production.

SILVA et al. (2006) published that Brachiaria brizantha has proved to be the species more tolerant to the compaction, also a study involving maize, soybeans and cotton, and that the density that provided the best development of this grass is close to $1.2 \mathrm{Mg} \mathrm{m}^{-3}$.

Studies involving the effect of compaction on the productive and morphological characteristics of grasses are scarce in the literature. Thus, this study aimed to investigate the effect of soil compaction in two forage grasses: Brachiaria brizantha cv. Xaraés, and Brachiaria brizantha cv. Marandu.

\section{MATERIAL AND METHODS}

The experiment was conducted in a greenhouse at the Faculdade de Agronomia e Medicina Veterinária of the Federal University of Mato Grosso, Cuiabá, State of Mato Grosso, Brazil. It was used a completely randomized experimental design, with eight treatments, arranged in a factorial design, and three replications; a total of 24 experimental units. Treatments consisted of two forage grasses (B. brizantha cv. Xaraés, and B. brizantha cv. Marandu) and four levels of compaction, represented by the soil densities of 1.0, 1.2, 1.4 and $1.6 \mathrm{Mg} \mathrm{m}^{-3}$.

The soil was an Argiluvic Plinthosol (EMBRAPA, 2006), having the following physical and chemical characteristics: 5.2 of $\mathrm{pH}\left(\mathrm{CaCl}_{2}\right) ; 20.4 \mathrm{mg} \mathrm{dm}^{-3}$ of $\mathrm{P} ; 94 \mathrm{mg} \mathrm{dm}^{-3}$ of $\mathrm{K} ; 2.1 \mathrm{cmol}_{\mathrm{c}} \mathrm{dm}^{-3}$ of $\mathrm{Ca} ; 1.0 \mathrm{cmol}_{\mathrm{c}} \mathrm{dm}^{-3}$ of $\mathrm{Mg} ; 3.2 \mathrm{cmol}_{\mathrm{c}} \mathrm{dm}^{-3}$ of $\mathrm{H} ; 0.0 \mathrm{cmol}_{\mathrm{c}} \mathrm{dm}^{-3}$ of $\mathrm{Al} ; 1.2 \mathrm{mg} \mathrm{dm}^{-3}$ of $\mathrm{Zn} ; 1.1 \mathrm{mg}$ $\mathrm{dm}^{-3}$ of $\mathrm{Cu} ; 257 \mathrm{mg} \mathrm{dm}^{-3}$ of Fe; $78.6 \mathrm{mg} \mathrm{dm}^{-3}$ of $\mathrm{Mn} ; 0.21 \mathrm{mg} \mathrm{dm}^{-3}$ of B; $6.2 \mathrm{mg} \mathrm{dm}^{-3}$ of S; $27.8 \mathrm{mg}$ $\mathrm{dm}^{-3}$ of MO; $696 \mathrm{~g} \mathrm{~kg}^{-1}$ of sand; $66 \mathrm{~g} \mathrm{~kg}^{-1}$ of Silte and $238 \mathrm{~g} \mathrm{~kg}^{-1}$ of clay. 
The experimental unit (pot) was manufactured using a cylinder of rigid PVC, with internal diameter of $195 \mathrm{~mm}$, made by overlapping the two rings. The upper ring, with a height of $60 \mathrm{~mm}$ and male plug of $5 \mathrm{~mm}$ at both ends; and the bottom ring, with a height of $145 \mathrm{~mm}$, female plug of $5 \mathrm{~mm}$ at the top and has had its bottom closed with anti-aphids knit of $1 \mathrm{~mm}$, fixed with rubber ring and tape.

The lower ring was filled with portions of soil sample with specified mass, for submitting density of $1.0 \mathrm{Mg} \mathrm{m}^{-3}$. In the upper ring, samples with respective masses of density levels of 1.0 , $1.2,1.4$ and $1.6 \mathrm{Mg} \mathrm{m}^{-3}$ have been accommodated. For ensuring the desired densities, the pots were weighed after the assembly and checked to verify if the soil mass has occupied the volume of the ring. Those which did not fit were discarded. The moisture content for compaction was defined using the Proctor test, in which was determined the humidity of $22 \%$ for compaction as optimum moisture. An hydraulic press, Charlott brand (PH5T model) - adapted with a plunger made of steel with $0.19 \mathrm{~m}$ of diameter, was used for compacting the soil in the intermediate ring.

In each pot were planted 15 seeds in the depth of $0.05 \mathrm{~m}$. Seven days after sowing, the rough grinding was done, leaving only five plants per pot. For the water supply has been adopted the methodology used by SILVA et al. (2006).

After 48 days of sowing, the number of tillers was quantified, and the plant height was measured, based on the ground level up to the ligula of the last fully expanded leaf. The age of the cutting was chosen according to SBRISSIA \& SILVA (2008) whom recommended that grasses of Brachiaria genre should be handled with average plant height between 0.30 and $0.40 \mathrm{~m}$. Following, collection was carried out from the shoots, cutting them at $0.05 \mathrm{~m}$ from the ground and, separating the components: stem and leaf. Subsequently, the material was dried in an oven $\left(65^{\circ} \mathrm{C}\right.$ for $\left.72 \mathrm{~h}\right)$, quantifying the dry matter (DM) of the shoot and its components (leaf and stem). It was also determined the leaf/stem relation, dividing the dry mass of the leaves by the dry mass of the stem. The roots were removed by washing in sieves, taken for drying $\left(65^{\circ} \mathrm{C}\right.$ for $\left.72 \mathrm{~h}\right)$ for determination of root DM production per pot.

The characterization of production and the morphology was given by the variables: production of dry mass of the shoot and roots; mass of stem, leaf mass, tiller population, plant height, leaf/stem relation, and shoot/root relation.

The results were tested for normality and homogeneity of variance. After acceptance of these assumptions, analysis of variance was performed using the F test, and when significant, regression analysis was applied to compare the level of compaction, and Scott-Knott test for comparison between the forages. For these procedures, the software MINITAB (version 15) was used.

\section{RESULTS AND DISCUSSION}

Variance analysis of production and morphological traits has revealed no significant effects for the forages (Table 1), indicating that the response of Xaraés and Marandu grasses were similar in function of soil compaction. The levels of soil compaction had a significant effect on leaf dry mass (LDM), stem dry mass (SDM), shoot dry mass (SDM) and root dry mass (RDM). The interaction between forage and level of compaction was significant only for LDM and SDM.

Tiller population was not influenced by levels of compaction, in which the overall mean was 14.62 tillers per pot. The same result was repeated for Piatã and mombaça grasses, according to BONELLI et al. (2011), in which the number of tillers was changed by the compaction only in the regrowth. Therefore, this response may have occurred by the fact that the forages were measured in the establishment, a result which probably would not be repeated in the regrowth. 
TABLE 1. Analysis of variance of morphological and productive traits of Xaraés and Marandu grasses at different levels of soil compaction.

\begin{tabular}{|c|c|c|c|c|}
\hline \multirow{2}{*}{ Variable } & \multicolumn{3}{|c|}{ Variation Source } & \multirow{2}{*}{ Coefficient of Variation (\%) } \\
\hline & Forage & Density & Interaction & \\
\hline Tiller Population & $0.1599^{\mathrm{ns}}$ & $0.3665^{\mathrm{ns}}$ & $0.1470^{\mathrm{ns}}$ & 16.10 \\
\hline Plants height $(\mathrm{mm})$ & $0.2827^{\mathrm{ns}}$ & $0.7787^{\mathrm{ns}}$ & $0.0539^{\mathrm{ns}}$ & 11.99 \\
\hline $\operatorname{LDM}^{1}\left(\mathrm{~g} \operatorname{pot}^{-1}\right)$ & $0.1137^{\mathrm{ns}}$ & $0.0357^{*}$ & $0.0101^{*}$ & 9.40 \\
\hline $\mathrm{SDM}^{2}\left(\mathrm{~g} \mathrm{pot}^{-1}\right)$ & $0.9075^{\mathrm{ns}}$ & $0.0287^{*}$ & $0.2368^{\mathrm{ns}}$ & 9.43 \\
\hline LDM/SDM relation & $0.1921^{\mathrm{ns}}$ & $0.6161^{\mathrm{ns}}$ & $0.0617^{\mathrm{ns}}$ & 15.50 \\
\hline $\mathrm{SDM}^{3}\left(\mathrm{~g}_{\operatorname{pot}^{-1}}\right)$ & $0.1452^{\mathrm{ns}}$ & $0.0026^{* *}$ & $0.0100^{*}$ & 6.45 \\
\hline $\mathrm{RDM}^{4}\left(\mathrm{~g}\right.$ pot $\left.^{-1}\right)$ & $0.0953^{\mathrm{ns}}$ & $0.0432^{*}$ & $0.9648^{\mathrm{ns}}$ & 20.32 \\
\hline SDM/RDM relation & $0.6636^{\mathrm{ns}}$ & $0.1151^{\mathrm{ns}}$ & $0.1958^{\mathrm{ns}}$ & 13.02 \\
\hline
\end{tabular}

1'LDM: leaf dry mass; ${ }^{2}$ SDM: stem dry mass; ${ }^{3}$ SDM: shoot dry mass; ${ }^{4} \mathrm{RDM}$ : root dry mass; ${ }^{\mathrm{ns}}$ Not significant by F test at 0.05 of probability. *** Significant at 0.01 and 0.05 of probability by $\mathrm{F}$ test, respectively.

Plant height was not affected by compaction, with an average of $0.398 \mathrm{~m}$. The response is considered normal for forage plants, once the time (48 days after sowing) was not enough for the forage to manifest their genetic potential or suffer the effect of compaction. SILVA et al. (2006) have studied the Brachiaria brizantha under levels of compaction, and collected the material exactly 96 days after germination, finding a reduction in the plant height due to the compaction, being defined the second-degree polynomial model as the best to represent the phenomenon under study.

Relations LDM/SDM and SDM/RDM were not affected by soil densities, indicating that the proportions have remained constant for all levels of compaction. The observed results for SDM/RDM, with an average of 6.65, were similar to those obtained by BONELLI et al. (2011), who realized that the relation SDM/RDM of Piatã and Mombaça grasses were not affected by levels of compaction. GUIMARÃES \& MOREIRA (2001), working with rice in the highlands under different levels of compaction, have not found changes for this variable in layer from 0 to $0.20 \mathrm{~m}$. In layer from 0.20 to $0.40 \mathrm{~m}$, the relation was affected in an exponential manner because of a reduction in RDM occasioned by increasing the soil compaction.

The relationship LDM/SDM may be used as an index of nutritive value of the forage, because as well as the height of grazing and dry mass availability, determines the ease of apprehension of forage by the animal and thus their ingestive behavior on grazing (ALDEN \& WHITAKER, 1970). The lack of effect was found for this relation was different from that observed in the literature, because it is common to observe an increase in mass of stems with the increase in compaction. BORGHI et al. (2007) found a similar response to this relation whilst studying Brachiaria brizantha in intercropping cultivation with maize under no-tillage system in different sampling dates, and attributed this fact to the shutdown of the growth of the forage, after cutting. In the present experiment it has not happened, which may be explained by a greater reallocation of photoassimilates to the emission of new tillers in detriment of growth of already existing tillers.

The SDM was affected by soil density in a similar manner for both forage and the result represented by the second degree polynomial model, significant by F-test at 0.05 of probability for all parameters (Figure 1). The maximum production of SDM (4.86 $\left.\mathrm{g} \mathrm{pot}^{-1}\right)$ was observed in soil density of $1.23 \mathrm{Mg} \mathrm{m}^{-3}$. 


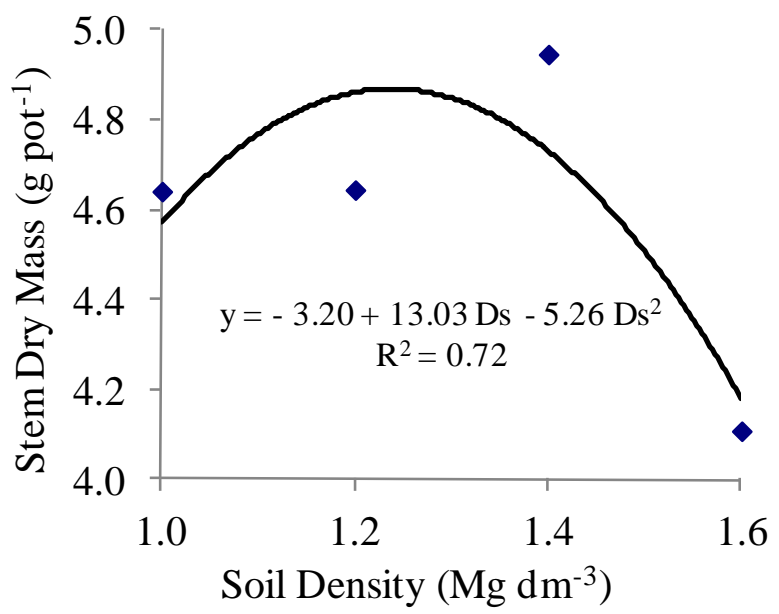

FIGURE 1. Production of Stem Dry Mass (SDM) of Xaraés and Marandu grass grasses under compaction levels.

Those variables where the interaction was significant (LDM, SDM and RDM), this occurred by the fact that, in greater compaction represented by the density of $1.6 \mathrm{Mg} \mathrm{m}^{-3}$, the Xaraés grass have produced more than Marandu grass, statistically different (Table 2). This behavior may reveal a greater tolerance of Xaraés grass to soil compaction, like rape and lupine under temperate conditions (TRÜKMANN et al., 2008).

TABLE 2. Breakdown of production data of Leaf Dry Mass (LDM) and Shoot Dry Mass (SDM) of the forages in the levels of soil compaction.

\begin{tabular}{ccccc}
\hline \multirow{2}{*}{ Forage } & \multicolumn{4}{c}{ Soil Density $\left(\mathrm{Mg} \mathrm{m}^{-3}\right)$} \\
\cline { 2 - 5 } & 1.00 & \multicolumn{4}{c}{1.20} & 1.40 & 1.60 \\
\cline { 2 - 5 } Xaraés grass & $11.12 \mathrm{a}$ & $9.79 \mathrm{a}$ & $11.28 \mathrm{a}$ & $10.72 \mathrm{a}$ \\
Marandu grass & $11.32 \mathrm{a}$ & $11.21 \mathrm{a}$ & $9.68 \mathrm{a}$ & $8.03 \mathrm{~b}$ \\
\hline \multicolumn{4}{c}{$\mathrm{SDM}\left(\mathrm{g} \mathrm{pot}^{-1}\right)$} \\
Xaraés grass & $15.46 \mathrm{a}$ & $14.67 \mathrm{a}$ & $16.03 \mathrm{a}$ & $14.89 \mathrm{a}$ \\
Marandu grass & $16.27 \mathrm{a}$ & $15.63 \mathrm{a}$ & $14.65 \mathrm{a}$ & $12.08 \mathrm{~b}$ \\
\hline
\end{tabular}

* Means followed by the same letter in column do not differ by Scott-Knott test at 0.05 of error probability.

Regarding the compaction, the found results for LDM and SDM were similar indicating that the major contribution to the SDM came from LDM. It was observed that the LDM and SDM of the Xaraés grass remained fairly constant in the levels of soil compaction, not adjusting to any regression model. The mass of leaf and shoot of the Xaraés grass was 10.73 and $15.25 \mathrm{~g} \mathrm{pot}^{-1}$. Results similar to those observed by Santos et al. (2008 b), which do not verify difference between the SDM of Brachiaria brizantha in densities from 1.0 to $1.6 \mathrm{mg} \mathrm{m}^{-3}$. In the case of Marandu grass the compaction has affected negatively in a linear way these components being possible the adjustment of first-degree polynomial model, with parameters significant at the 0.05 of probability by $\mathrm{F}$ test (Figure $2 \mathrm{a}$ and $\mathrm{b}$ ).

The results observed for Marandu grass were similar to those observed by GUIMARÃES \& MOREIRA (2001), 40 days after emergence, working with rice in the highlands under tracks of compaction, and by ROSOLEM et al. (1994) for soybean cultivation. 

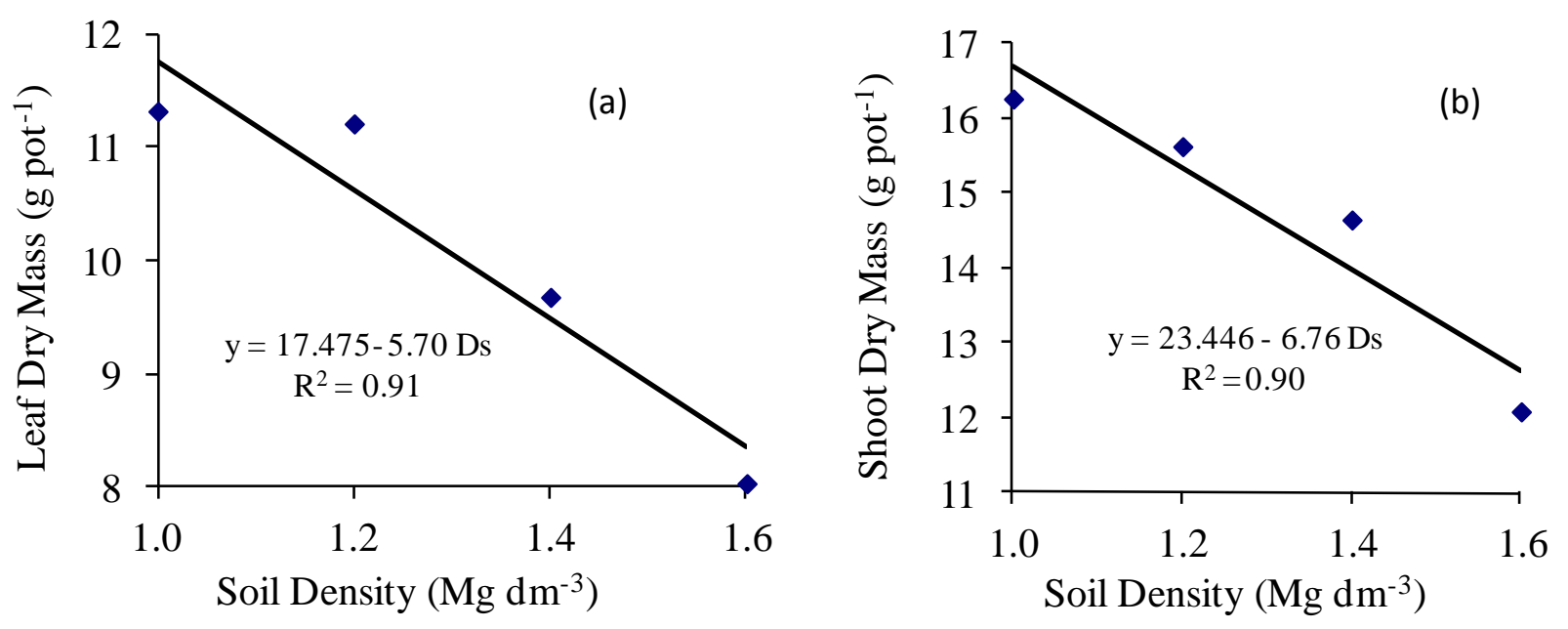

FIGURE 2. Production of Leaf Dry Mass (LDM) (a) and Shoot Dry Mass (SDM) (b) of Marandu grass in levels of soil compaction.

ATWELL (1990) has assigned the lowest growth of wheat plants under conditions of soil compaction to the lowest absorption of the more leachable nutrients, as $\mathrm{N}$ and $\mathrm{K}$, since the root system present in the soil surface layer has supplied properly the plant with $\mathrm{P}$. Then, this may indicate a greater capacity of the Xaraés grass to absorb nutrients regardless of soil density in the experimental conditions of this study.

Root growth of Xaraés and Marandu grasses has been similarly affected by soil compaction. The response of root mass was contrary to the variables which had an influence of compaction, in other words, it was observed an increase of the RDM with the increase of density (Figure 3). This fact may be attributed to the pursuit of forage on minimizing the effects of compaction with the emission of roots, in order to supply their needs for water and nutrients, or even by increasing the diameter of the existing roots according to FREDDI et al. (2007). Thus, the evaluation of the spatial distribution of roots in addition to the determination of dry mass of them may bring greater information and help to clarify the response of the root system under soil compaction tracks.

Similar to what occurs in grasses under grazing, the plant always prioritizes the limiting resource, that in this situation has been the production of leaves. Thus, the plant shall reallocate the photo-assimilated compounds of the roots to form the new shoot, a fact that has been evident in this study, where the grass under conditions of adequate moisture and fertilizer had as impediment to its development just the barrier imposed by the layer of compacted soil under the root system.

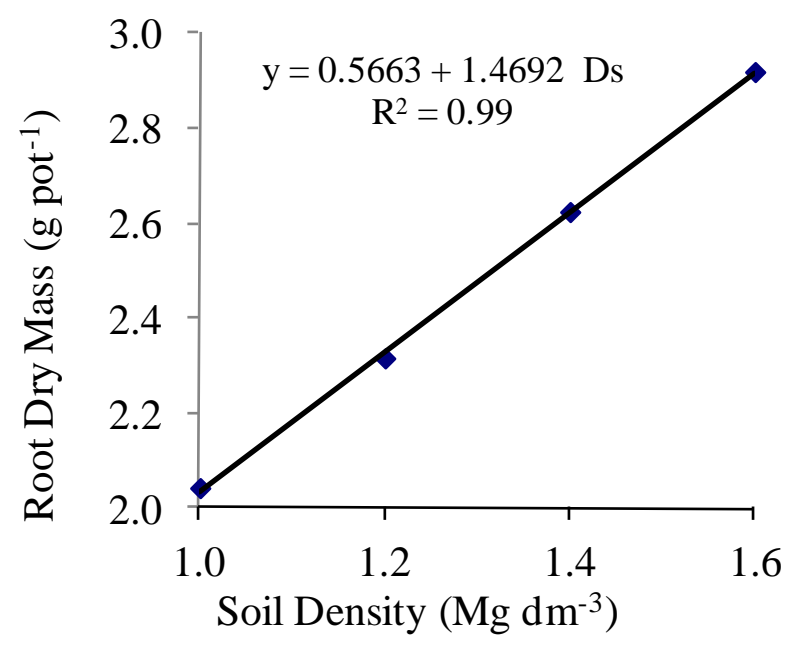

FIGURE 3. Root Dry Mass (RDM) of Xaraés and Marandu grasses under compaction levels. 
RODRIGUES et al. (2008) affirm that there is variation in the source/drain relation, in which the plant directs the energy of production of the shoot for the formation of its root system. FREDDI et al. (2007), studying soil compaction on root growth and productivity of maize crop, also reported an increase in density and root surface in the layer from 0 to $10 \mathrm{~cm}$ with the increase of compaction. GONÇALVES et al. (2006) observed that the grasses "pé-de-galinha" (Eleusine coracana) and kenaf (Hybiscus cannabinus) were not sensitive to the increase in soil compaction, although with less accumulation of RDM in all layers. Conversely, GUIMARÃES \& MOREIRA (2001) have observed a reduction in root growth of rice in densities above $1.2 \mathrm{Mg} \mathrm{m}^{-3}$. Similar results were observed by ROSOLEM et al. (1994).

\section{CONCLUSIONS}

The establishment of Xaraés grass has not been adversely affected by soil compaction up to the density of $1.6 \mathrm{Mg} \mathrm{m}^{-3}$, because there are no changes in the variables adopted for the assessment of production. On the other hand, the dry mass of stem has reduced with the increasing in compaction, which suggests that this grass may be indicated for situations where there may be layers which restrict the growth of different forage species.

The development of Marandu grass is limited by an increment in soil compaction, with a reduction in production of dry mass of shoots and leaves as there is an increase in the density of the soil.

\section{REFERENCES}

ALDEN, W.G.; WHITAKER, I.A. The determinants of herbage intake by grazing sheep: the inter relationship o'f factors influencing herbage intake and availabity. Australian Journal of Agricultural Research, Victoria, v.21, p.755-766, 1970.

ATWELL, B. J. The effect of soil compaction on wheat during early tillering. New Phytologist, Cambridge, v.115, p.29-35, 1990 .

AZEVEDO, E.C.; SVERZUT, C.B. Alterações dos atributos físicos e químicos do solo sob pastagem no sudoeste do estado de Mato Grosso. Revista Agricultura Tropical, Cuiabá, v.9, n.1, p.1-17, 2007.

BARBOSA, R.A.; NASCIMENTO JÚNIOR, D.; EUCLIDES, V.P.B.; SILVA, S.C.; ZIMMER, A.H.; TORRES JÚNIOR, R.A.A. Capim-tanzânia submetido a combinações entre intensidade e freqüência de pastejo. Pesquisa Agropecuária Brasileira, Brasília, v.42, n.3, p.329-340, 2007.

BENGOUGH, A.G.; CROSER, C.; PRITCHARD, J. A biophysical analysis of root growth under mechanical stress. Plant and Soil, Dordrecht, v.189, p.155-164, 1997.

BONELLI, E.A.; BONFIM-SILVA, E.M.; CABRAL, C.E.A.; CAMPOS, J. J.; SCARAMUZZA, W.L.M.P.; POLIZEL, A.C. Compactação do solo: Efeitos nas características produtivas e morfológicas dos capins piatã e mombaça. Revista Brasileira de Engenharia Agrícola e Ambiental, Campina Grande, v.15, n.3, p.264-269, 2011.

BORGHI, E.; MOBRICCI, C.; PULZ, A.L.; ONO, E.O.; CRUSCIOL, C.A.C. Crescimento de Brachiaria brizantha em cultivo consorciado com milho em sistema de plantio direto. Acta Scientiarum. Agronomy, Maringá, v.29, n.1, p.91-98, 2007.

EMBRAPA. EMPRESA BRASILEIRA DE PESQUISA AGROPECUÁRIA. Sistema brasileiro de classificação de solos. Brasília: Embrapa-SPI; Rio de Janeiro, Embrapa-Solos, 2006. 306 p.

EUCLIDES, V.P.B.; THIAGO, L.R.L.; MARCELO, M.C.M.; OLIVEIRA, M.P. Consumo voluntário de forragem de três cultivares de Panicum maximum sob pastejo. Revista Brasileira de Zootecnia, Viçosa-MG, v.28, n.6, p.1177-1185, 1999. 
FERREIRA, R.R.M.; TAVARES FILHO, J.; FERREIRA, V.M. Efeitos de sistemas de manejo de pastagens nas propriedades físicas do solo. Semina: Ciências Agrárias, Londrina, v.31, n.4, p.913932, 2010.

FREDDI, O.S.; CENTURION, J.F.; BEUTLER, A.N.; ARATANI, R.G.; LEONEL, C.L. Compactação do solo no crescimento radicular e produtividade da cultura do milho. Revista Brasileira de Ciência do Solo, Viçosa-MG, v.31, n.4, p.627-636, 2007.

GOMIDE, C.A.M.; GOMIDE, J.A.; ALEXANDRINO, E. Características estruturais e produção de forragem em pastos de capim-mombaça submetidos a períodos de descanso. Pesquisa Agropecuária Brasileira, Brasília, v.42, n.10, p.1487-1494, 2007.

GONÇALVES, W.G.; JIMENEZ, R.L.; ARAÚJO FILHO, J.V.; ASSIS, R.L.; SILVA, G.P.; PIRES, F.R. Sistema radicular de plantas de cobertura sob compactação do solo. Engenharia Agrícola, Jaboticabal, v.26, n.1, p.67-75, 2006.

GONTIJO NETO, M.M.; EUCLIDES, V.P.B.; NASCIMENTO JR., D.; MIRANDA, L.F.; FONSECA, D.M.; OLIVEIRA, M.P. Consumo e tempo diário de pastejo por novilhos Nelore em pastagem de capim-tanzânia sob diferentes ofertas de forragem. Revista Brasileira de Zootecnia, Viçosa-MG, v.35, n.1, p.60-66, 2006.

GUIMARÃES, C.M.; MOREIRA, J.A.A. Compactação do solo na cultura do arroz de terras altas. Pesquisa Agropecuária Brasileira, Brasília, v.36, n.4, p.703-707, 2001.

PINTO, J.C.; GOMIDE, J.A.; MAESTRI, M. Produção de matéria seca e relação folha/caule de gramíneas forrageiras tropicais, cultivadas em vasos, com duas doses de nitrogênio. Revista Brasileira de Zootecnia, Viçosa-MG, v.23, n.3, p.313-326, 1994.

RODRIGUES, R.C.; MOURÃO, G.B.; BRENNECKE, K.; LUZ, P.H.C.; HERLING, V.R. Produção de massa seca, relação folha/colmo e alguns índices de crescimento do Brachiaria brizantha $\mathrm{cv}$. Xaraés cultivado com a combinação de doses de nitrogênio e potássio. Revista Brasileira de Zootecnia, Viçosa-MG, v.37, n.3, p.394-400, 2008.

ROSOLEM, C.A.; ALMEIDA, A.C.S.; SACRAMENTO, L.V.S. Sistema radicular e nutrição da soja em função da compactação do solo. Bragantia, Campinas, v.53, n.2, p.259-266, 1994.

SANTOS, J.B.; LÁZARI, T.M.; CAMELO, G.N.; OLIVEIRA, T.A.; FIGUEIREDO, J.L.A. Competição entre soja resistente ao glyphosate e plantas daninhas em solo compactado. Planta Daninha, Viçosa-MG, v.26, n.1, p.123-130, 2008b.

SANTOS, L.C.; BONOMO, P.; SILVA, C C.F.; PIRES, A.J.V.; VELOSO, C.M.; PATÊS, N.M.S. Produção e composição química da Brachiaria brizantha e Brachiaria decumbens submetidas a diferentes adubações. Ciência Animal Brasileira, Goiânia, v.9, n.4, p.856-866, 2008 a.

SARMENTO, P.; RODRIGUES, L.R.A.; CRUZ, M.C.P.; LUGÃO, S.M.B.; CAMPOS, F.P.; CENTURION, J.F.; FERREIRA, M.E. Atributos químicos e físicos de um Argissolo cultivado com Panicum maximum Jacq. cv. IPR-86 milênio, sob lotação rotacionada e adubado com nitrogênio. Revista Brasileira de Ciência do Solo, Viçosa-MG, v.32, n.2, p.183-193, 2008.

SBRISSIA, A.F.; SILVA, S.C. Compensação tamanho/densidade populacional de perfilhos em pastos de capim-Marandu. Revista Brasileira de Zootecnia, Viçosa-MG, v.37, n.1, p.35-47, 2008.

SEVERIANO, E.C.; OLIVEIRA, G.C.; DIAS-JUNIOR, M.S.; COSTA, K.A.P.; CASTRO, M.B.; MAGALHÃES, E.N. Potencial de descompactação de um Argissolo promovido pelo capim-tifton 85. Revista Brasileira de Engenharia Agrícola e Ambiental, Campina Grande, v.14, n.1, p.39-45, 2010.

SILVA, C.J.A.; DITTRICH, J.R.; MONTEIRO, A.L.G.; MORAES, A.; BARROS, C.S.; OLIVEIRA, E.B. Preferência de caprinos em pastejo: efeito da altura dos dosséis das forrageiras aruana e hemártria. Ciência Animal Brasileira, Goiânia, v.10, n.3, p.698-710, 2009. 
SILVA FILHO, E.P.; COTTAS, L.R.; MARINI, G.B.S. Avaliação da compactação dos solos em áreas de pastagens e florestas em Porto Velho-Rondônia. Boletim de Geografia, Maringá, v.28, n.1, p.145-155, 2010.

SILVA, G.J.; MAIA, J.C.S.; BIANCHINI, A. Crescimento da parte aérea de plantas cultivadas em vaso, submetidas à irrigação subsuperficial e a diferentes graus de compactação de um Latossolo Vermelho-Escuro distrófico. Revista Brasileira de Ciência do Solo, Viçosa-MG, v.30, n.1, p.31-40, 2006.

SILVA, G.J.; VALADÃO JÚNIOR, D.D.; BIANCHINI, A.; AZEVEDO, E.C.; MAIA, J.C.S. Variação de atributos físico-hídricos em Latossolo vermelho-amarelo do Cerrado Mato-Grossense sob diferentes formas de uso. Revista Brasileira de Ciência do Solo, Viçosa-MG, v.32, n.5, p.21352143, 2008.

SPERA, S.T.; SANTOS, H.P.; FONTANELI, R.S.; TOMM, G.O. Efeito de pastagens de inverno e de verão em características físicas de solo sob plantio direto. Ciência Rural, Santa Maria, v.36, n.4, p.1193-1200, 2006.

TRÜKMANN, K.; REINTAM, E.; KUHT, J.; NUGIS, E.; EDESI, L. The effect of soil compaction on wheat during early tillering. Agronomy Research, Saku, v.6, n.1, p.101-108, 2008. 